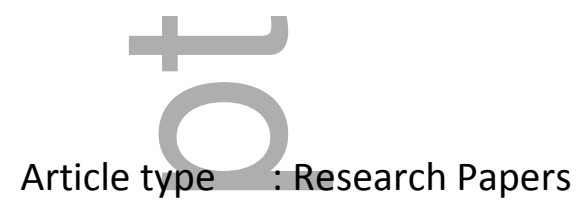

Article type : Research Papers
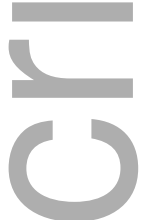

Corresponding author mail id : belinda.osullivan@monash.edu

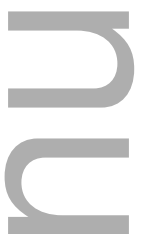

\title{
Duration and setting of rural immersion during the medical degree relates to rural work outcomes
}

\begin{abstract}
Context: Providing year-long rural immersion as part of the medical degree is commonly used to increase doctors with rural practice interests. However, the optimal duration and setting of immersion has not been fully established.
\end{abstract}

This is the author manuscript accepted for publication and has undergone full peer review but has not been through the copyediting, typesetting, pagination and proofreading process, which may lead to differences between this version and the Version of Record. Please cite this article as doi: $10.1111 /$ medu.13578

This article is protected by copyright. All rights reserved 
Objectives: This paper explores associations between various durations and settings of rural immersion during the medical degree and whether doctors work in rural areas after graduation.

Methods: Eligible participants were medical graduates of Monash University between 2008 and 2016, in postgraduate year 1-9, whose characteristics, rural immersion information and work location had been prospectively collected. Separate multiple logistic regression and multinomial logit regression models tested associations between the duration and setting of any rural immersion during the medical degree and a) working in a rural area and b) working in large or smaller rural towns, in 2017.

Results: The adjusted odds of working in a rural area were significantly increased if students were immersed for one full year (OR 1.79, 95\% $\mathrm{Cl} 1.15-2.79)$, for between one to two years (OR 2.26, 95\% Cl 1.54-3.32) and for two or more years (OR $4.43,95 \% \mathrm{Cl}$ 3.03-6.47) relative to no rural immersion.

The strongest association was for immersion in a mix of both regional hospitals and rural general practice (OR 3.26, 95\% Cl 2.31-4.61), followed by immersion in regional hospitals only (OR 1.94, 95\% Cl 1.39-2.70) and rural general practice only (OR 1.91, 95\% $\mathrm{Cl}$ 1.06-3.45). More than one years' immersion in a mix of regional hospitals and rural general practices was associated with working in smaller regional or rural towns ( $<50,000$ population) (RRR $2.97,95 \% \mathrm{Cl} 1.82-4.83)$.

Conclusion: These findings inform medical schools about effective rural immersion programs. Longer rural immersion and immersion in both regional hospitals and rural general practices are likely to increase rural work and rural distribution of early career doctors.

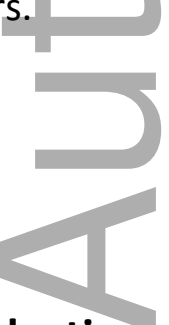

\section{Introduction}

Medical school curricula play an important role in shaping doctors' future career directions, as do the professional and social networks formed during the intensive 
years of a medical degree. Rural immersion programs, involving students living and doing their clinical training in rural areas over sustained periods, are increasingly being implemented as an avenue for developing more rural doctors (1-3). Rural immersion aims to develop the student's insights into rural health, as well as skills and interests that may lead them into rural medical practice. However, the potential for immersion to influence doctors working in rural areas is likely to be affected by where it occurs and by its duration. Critically, there is limited high quality evidence about the optimal duration and setting of immersion as a means of increasing the uptake of rural work $(4-6)$.

Such evidence is urgently needed to inform national policy in Australia which, since 2000, has progressively funded nineteen medical schools to deliver a minimum one years' rural immersion for at least $25 \%$ of all enrolled students and ensures that at least $25 \%$ of all students have a rural background. Australia was the first country to develop such a national policy but policy and program development in Australia and abroad depends on evidence about the types of immersion designs that are most effective.

A key limiting factor for the generation of such evidence is that many medical schools in Australia and internationally provide only a fixed duration and single location for each student's immersion (7-9). This has limited the capacity to compare within any one medical school, any effects of different durations and settings of immersion. An additional limitation of the extant evidence is that medical courses offering fully regionalised medical courses do not have a metropolitan-trained group with which to make internal comparisons as to program outcomes $(3,10)$.

There is also wide variation in the quality of research with respect to isolating design effects. Rural immersion is only one of many policy responses targeting improved rural medical workforce distribution (11). However, other than rural background which is now commonly studied as an independent predictor of rural practice and as a factor which increases the effects of rural immersion, many studies do not adequately account for rural service obligations. Two key types in Australia are domestic students undertaking their medical degree on rural-bonded medical places or scholarships and international students who incur temporary visa restrictions upon graduation requiring 
them to work in underserved areas, many of which are rural to access a billing provider number (at least two to five years rural service can be required depending on remoteness of the location) (5) (12). Moreover, emerging evidence suggests that student interest in rural practice may also be associated with rural work outcomes (13, 14). However, this needs to be confirmed through multivariate analysis. Finally, the effect of immersion duration and setting on achieving graduates who work in smaller rural and remote communities, as opposed to larger regional cities has not been studied, despite its relevance for shaping policies that address medical workforce distribution to these areas.

A limited number of Australian studies have explored the effect of different durations of immersion on rural practice but only three cover rural practice outcomes beyond the first post-graduate year (PGY1) $(15)(16,17)$. One and two years' immersion was related to up to three and five times the odds of doctors spending at least $50 \%$ of their postgraduate time in rural areas (up to PGY10) compared with no immersion (17). Additional research about a possible dose-response effect of a wider range of increments of rural immersion is warranted. Furthermore, aside from one published study suggesting that immersion in rural general practice is more strongly related to rural work orientation than immersion in a regional hospital, there is no other research about the influence of different immersion settings (18).

This study is based on a large-scale single university medical program that offers a range of immersion experiences. Using this unique dataset, it aims to explore the relationship between a range of durations and settings of rural immersion during medical school and subsequent rural work and rurality of work location after graduation, applying a metropolitan-trained control group as an internal control and investigating all likely, measurable covariates.

\section{Methods}

\section{Study sample}

This article is protected by copyright. All rights reserved 
This longitudinal study was based within Monash University's medical school, in Victoria, Australia with ethics approval by Monash University's human research ethics committee (Ref: CF14/3302 - 201400174). Monash University graduates over 300 medical students annually through either direct (5 year) or graduate entry (4 year), which converge for the final 3 years of clinical training.

Both domestic and limited international students are able to self-select to undertake part of the course in rural areas in south-eastern and north-western regional clinical schools, on an opt-in basis in years 3, 4 and 5 (Table 1). Each year, all students nominate their preferences for rural or metropolitan training locations, with sufficient rural training positions available to accommodate all students nominating for rural training. Additionally, 30 direct-from school (direct) entry students opt-in at course entry, to a pre-arranged rural training pathway involving a mix of regional and rural exposures of minimum two and a half years' duration. Students on rural placements receive part-subsidisation for their accommodation costs, and assistance with travel costs undertaken while completing course activities, but few other incentives.

Eligible participants were those who commenced their medical degree after 2004 who graduated and entered medical practice between 2008 and 2016. They were in PGY 1 to 9 at the time that rural practice outcome measurement was undertaken in 2017.

\section{Exposure}

Information about the location and setting of different periods of training by each student in years 3 to 5 was prospectively collected from university administrative systems and verified by regional training coordinators. The duration of rural immersion was defined by aggregating all periods of training (weeks) in years 3 to 5 that occurred in metropolitan or rural locations, geocoded based on the Australian Standard Geographical Classification-Remoteness Areas (ASGC-RA) schema (1). These were then grouped into five incremental categories based on the standard training periods (noting that 36 teaching weeks constitutes one standard academic year). These were: (1) metropolitan only (including 0 to 6 weeks training in rural areas); or rural for $(2)<1$ year; (3) exactly 1 year; (4) > 1 and $\leq 2$ years; (5) >2 years (to a maximum of three). 
The setting was defined based on the range of training location/s that students undertook immersion in years 3 to 5 (as shown in Table 1). These included training occurring: 1) only in metropolitan areas; 2 ) wholly in regional hospitals; 3) wholly in rural general practices, or 4) a mix of both regional hospitals and rural general practices. The final year (year 5) six-week clinical rotations, including a six-week clinical elective were only included in the analyses of 'setting' if students undertook more than one rotation in rural areas, totalling at least 12 weeks' duration.

A combined 'duration and setting' variable was also defined based on the same four setting groups and the duration, collapsed into up to, or more than one year, to avoid small cell counts.

\section{Student characteristics}

Rural background was defined as having resided for at least five years since commencing primary school in an area classified as rural according to the ASGC-RA2-5 (19). Students self-identify this by submitting a statutory declaration on enrolment into medical school.

Other relevant covariates included age, sex, direct-= or graduate course entry (completed another degree prior to entering medicine), postgraduate year, international student status (domestic or international) and recipients of either a Bonded Medical Place (BMP) or Medical Rural Bonded Scholarship (MRBS) (described in Table $2^{\mathrm{b}}$ ).

Self-reported prospective interest in working after graduation in a rural area (outside of a capital city or major urban centre) and interest in becoming a general practitioner (top three of list of 18 specialty preferences, other, or not decided) at course commencement were obtained from the Medical Student Outcomes Database (MSOD) and linked by the student identification number (20). These data were only available for the 2006-2014 commencing cohorts. To avoid dropping unmatched students from multiple regression analysis, which used list wise deletion, the two 'interest' variables were categorised "yes", "no" or "unknown". 


\section{Outcome measure}

The outcome of interest was the graduate's main work location, obtained from the Australian Health Practitioner Regulation Agency's public website annually in 2014 until 2017 and linked by student first and last name to their characteristics and training information.

Work location was geocoded (by town name and postcode) and categorised using the Australian-standard Modified Monash Model (MMM) rurality scale as: MMM-1 'metropolitan' and MMM 2-7 'rural'. Practice outcomes were also explored by geographical distribution, using MMM-1 'metropolitan', MMM-2 'large regional' ( $\geq 50,000$ population) and MMM 3-7 'smaller regional and rural towns' $\quad<50,000$ population).

A cross-sectional analysis of the 2017 work location was done, incorporating graduates spanning PGYs 1-9. Two sensitivity analyses using alternate outcome measures were undertaken: 1) cross-sectional analyses of 2016 work location outcomes; and 2) longitudinal analysis using generalised estimating equations which aggregated years of rural work in 2014- 2017.

\section{Analyses}

Simple logistic regression tested associations between rural work location in 2017 and each of: 1) the duration; 2) the settings of rural immersion; and 3) student characteristics. Three multiple logistic regression models then explored associations with rural work location, after adjusting for significant variables from univariate analysis (calculated as odds ratios (ORs)). A further three multiple multinomial logit regression models explored associations (calculated as relative risk ratios (RRR)), between immersion duration and setting and doctors working in metropolitan, large regional ( $\geq 50,000$ population) or smaller regional/rural towns $(<50,000$ population). In the multiple regression models, graduate or direct entry was used instead of age as this was correlated and considered amenable to policy intervention. StataSE v14.2 
(StataCorp, https://www.stata.com/) was used for all statistical analyses and $p<0.01$ was considered statistically significant, although $p<0.05$ is also reported.

\section{Results}

Overall 2,412 graduates were registered and working in 2017 and 42 (1.9\%) of domestic and $316(52.6 \%)$ international students were excluded as they had no identifiable work location, mainly due to pursuing their medical registration and ongoing career outside of Australia. Of the included graduates, $14.0 \%$ were working in a rural area.

\section{Any rural work location}

Univariate analysis in Table 2 showed a strong dose-response effect between increasing the duration of immersion and an increasing proportion of graduates working in rural areas in 2017 (from nil: 8.7\%, less than one year: 10.6\%, one year: $15.0 \%$, up to two years: $19.5 \%$ and more than two years: $39.2 \%)(p<0.001)$. Also a higher proportion of students immersed in both regional hospitals and rural general practices were working rurally (29.7\%) compared with those based only in either regional hospitals $(17.3 \%)$ or rural general practices $(13.6 \%)(p<0.001)$.

After accounting for rural background, direct or graduate entry, sex, international student status, BMP, MRBS, interest in working in a rural areas, interest in becoming a general practitioner and postgraduate stage in multivariate analyses, the strongest odds of rural work were for those immersed for two or more years (OR $4.43,95 \% \mathrm{Cl}$ 3.03-6.47) $(p<0.01)$ compared with no immersion (Table 3). The dose-response effect was maintained, though immersion of less than one year was no longer significant. Immersion in both regional hospitals and rural general practice settings (OR 3.26, 95\% $\mathrm{Cl}$ 2.31-4.61) had the strongest associations with rural work, followed by regional hospitals only (OR 1.94, 95\% Cl 1.39-2.70) and rural general practice only (OR 1.91, 95\% $\mathrm{Cl}$ 1.06-3.45). When the duration and setting of immersion were combined, more than one year in both regional hospitals and rural general practices had the strongest association with subsequently working in a rural area (OR 3.67, 95\% $\mathrm{Cl}$ 2.54-5.28). 


\section{Rurality of work location}

Multivariate analysis showed that more than two years of immersion was strongly related to working in a large regional centre $\phi, 000$ population) compared to no immersion, (RRR 5.77 95\% Cl 3.51-9.49) (Table 4). Working in smaller regional or rural towns $(<50,000$ population) was significantly associated with immersion of greater than one year (for 1-2 years: RRR $2.4495 \% \mathrm{Cl} 1.51-3.94$; and for $>2$ years: RRR $3.3495 \%$ $\mathrm{Cl} 2.02-5.52)$.

Immersion in both regional hospitals and rural general practices was associated with increased odds of students working in either larger regional centres or smaller regional centres or rural towns (RRR 3.72 95\% Cl 2.35-5.87 and RRR 2.73 95\% Cl 1.72-4.32, respectively). The likelihood of working in large regional centres or in smaller regional or rural towns, respectively, was greatest if students were immersed for more than one year in both regional hospitals and rural general practices (RRR 4.31 95\% Cl 2.666.99 and RRR $2.9795 \% \mathrm{Cl} 1.82-4.83)$, compared to no rural immersion.

\section{Other influences}

All multivariate analyses showed consistently statistically significant associations related to student's rural background, graduate entry, rural return-of-service obligations and international students, with their increased odds of working in any rural location of 3.39, 1.66, 1.62 and 5.78, respectively, in model 3a, Table 3 (all were $\mathrm{p}<0.001)$. Graduates in postgraduate stages 5-6 and 7-9 had significantly decreased odds of rural work ( 0.56 and 0.55 relative to those in PGY $1-2(p<0.001)$. Interest in working in a rural area or becoming a general practitioner at course commencement and sex were not significantly associated with working in a rural location after accounting for other covariates.

However, by rurality of outcomes, being a graduate entry student and having an interest in working in a rural area at course commencement (RRR $2.1195 \% \mathrm{Cl}$ 1.413.18 and RRR $1.9095 \% \mathrm{Cl}$ 1.15-3.12 respectively) were associated with working in smaller regional or rural towns relative to metropolitan locations and not in large regional centres $\left(\begin{array}{lllllllll}\mathrm{RRR} & 1.16 & 95 \% \mathrm{Cl} & 0.73-1.84 & \text { and } & \mathrm{RRR} & 0.96 & 95 \% \mathrm{Cl} & 0.56-1.63\end{array}\right.$ respectively), in model $3 b$, Table 4 . 
Stratification of rural work location outcomes by rural background, duration and setting of rural immersion (Figure 1) showed that rural immersion of at least one year approximately doubled the proportion of both the metropolitan and rural-background students working rurally.

Sensitivity analyses using (1) 2016 and (2) aggregate of 2014-17 outcomes both revealed very similar associations (Appendix S1 available online), supporting that the 2017 work location was a valid outcome to use in the study.

\section{Discussion}

This is the first study to explore the relationship between different durations of immersion and the likelihood of medical graduates working in rural areas in different sized towns during their early career. The findings support policy directions of providing a minimum of one year of rural immersion to increase rural medical workforce supply, which is relatively common program structure internationally (1), though some highly structured rural-orientated programs are shorter(8). Importantly, the study extends the evidence to show a clear dose-response relationship between increasing the duration of immersion to longer than one year, up to two and more than two years (up to a maximum of three years) as increasing the odds of rural work location.

This study additionally shows that the setting in which immersion occurs may relate to rural work outcomes, with a combination of regional hospital and general practice settings being very strongly related to working in large or smaller communities, particularly with more than one year's immersion. It is possible that training students across a range of rural settings (not only in larger regional hospitals or general practices), may help to prepare them for the full realm of rural practice, building skills and networks in both acute and community care. Medical schools may achieve improved rural workforce outcomes by developing longer than one year's rural immersion in a range of settings, though this study was limited to a large Victorianbased cohort of students and results may vary in countries and regions with different rural workforce policies, geography and rural population distribution. . 
Independent of the structure of immersion, a student's characteristics have a similar strength of association with whether graduates end up working in rural areas. As such, medical courses should ideally consider student selection as well as optimal rural immersion program designs to maximise rural workforce outcomes. Important characteristics identified in this study include graduate course entry, rural return-ofservice obligations or international student status, and the well-described ruralbackground effect. Of note, our study suggests that the importance of fostering students with initial interests in working in rural areas is not sustained after accounting for other factors, but is relevant for increasing doctors who work in smaller regional or rural towns, which often struggle the most to attract and retain doctors (21). This finding differs from other studies that found an interest in rural practice and general practice was associated with any rural practice, possibly because the present study accounted for all likely confounders of the rural immersion experience and explored rural location outcomes with more granularity $(13,22)$. Our findings confirm other research showing a differential influence of rural immersion duration on rural and metropolitan background students $(9,16)$.

Though this study is based on a large cohort from a single university, the large and diverse nature of the rural programs offered, and the availability of a metropolitantrained control group, allows unique exploration of a range of characteristics of rural immersion within its program. By carefully measuring and accounting for a range of other influences on rural outcomes, this study helps to identify significant associations between rural work location and the program design, although the results only pertain to early career location choices and longer-term studies are needed. The study was based on a predominantly self-selecting rural cohort. Although it accounted for measurable covariates related to self-selection (interest in working in a rural area, interest in being a general practitioner, rural background and nominating to enter the course with rural return of service obligations), the study could not account for whether students received their highest priority choice of immersion location. Generally, rural training is widely subscribed to and there are sufficient placements to accommodate all interested students, but occasionally training location preferences are not matched. 
An additional limitation is that our data were not able to identify the exact rural location of the 6-weekly rotations between the hospital and general practices in a regional centre for $50 \%$ of students in year 4 who were based in two of the four regional hospitals. This group were categorised as 'regional hospital', potentially under-estimating the effect of mixed regional hospitals and general practice exposures.

\section{Conclusion}

This study provides strong evidence of improved rural workforce outcomes related to longer duration rural immersion programs, with the strongest effects occurring when students had a mix of immersion in both regional hospitals and rural general practices. This effect is evident irrespective of rural-bonding policies, student's rural background or prior rural interest. Although one year of immersion had a moderate effect, incremental increases in the duration of immersion up to two and half years, was associated with higher proportions of early career doctors working in rural areas, whether in large regional centres of smaller regions or rural towns. The results suggest rural medical schools may improve outcomes by considering longer duration and a mixed range of settings of immersion as part of program planning.

\section{References}

1. Rabinowitz HK, Diamond JJ, Markham FW, Hazelwood CE. A program to increase the number of family physicians in rural and underserved areas: Impact after 22 years. JAMA 1999;281:255-60.

2. Hogenbirk J, Timothy P, French M, Strasser R, Pong R, Cervin C, et al. Milestones on the social accountability journey: Family medicine practice locations of Northern Ontario School of Medicine graduates. Canadian Family Physician 2016;62:e138-45.

3. Inoue K, Hirayama Y, Igarashi M. A medical school for rural areas. Medical Education 1997;31:430-4. 
4. Barrett F, Lipsky M, Nawal Lutfiyya M. The Impact of Rural Training Experiences on Medical Students: A Critical Review. Academic Medicine 2011;86:259-63.

5. Farmer J, Kenny A, McKinstry C, Huysmans RD. A scoping review of the association between rural medical education and rural practice location. Human Resources for Health 2015;13:1-15.

6. O'Sullivan BG, McGrail M, Russell D, Chambers H, Major L. A review of characteristics and outcomes of Australia's undergraduate medical education rural immersion programs. Human Resources for Health (in press) 2018.

7. Rabinowitz HK, Diamond JJ, Markham FW, Paynter NP. Critical factors for designing programs to increase the supply and retention of rural primary care physicians. JAMA 2001;286:1041-8.

8. Halaas GW, Zink T, Finstad D, Bolin K, Center B. Recruitment and Retention of Rural Physicians: Outcomes From the Rural Physician Associate Program of Minnesota. The Journal of Rural Health 2008;24:345-52.

9. Playford D, Evans S, Atikinson D, Auret K, Riley G. Impact of the Rural Clinical School of Western Australia on work location of medical graduates. Medical Journal of Australia 2014;200:104-7.

10. Ray R, Woolley T, Sen Gupta T. James Cook University's rurally orientated medical school selection process: quality graduates and positive workforce outcomes. Rural and Remote Health 2015;15:1-11.

11. Mason J. Review of Australian government health workforce programs. Canberra: Department of Health and Ageing, 2013.

https://www.health.gov.au/internet/main/publishing.nsf/Content/D26858F4B68834E ACA257BF0001A8DDC/\$SFile/Review\%20of\%20Health\%20Workforce\%20programs.pdf (accessed 29 January 2018).

12. National Rural Health Student Network. Bonded Medical Schemes: research outcomes report. Melbourne: Rural Health Workforce Australia, 2016.

13. Playford D, Ngo H, Gupta S, Puddey I. Opting for rural practice: the influence of medical student origin, intention and immersion experience. Medical Journal of Australia 2017;4:154-8.

This article is protected by copyright. All rights reserved 
14. Clark T, Freedman S, Croft A, Dalton H, Luscombe G, Brown A, et al. Medical graduates becoming rural doctors: rural background versus extended rural placement. Medical Journal of Australia 2013;199:779-82.

15. Forster L, Assareh H, Watts LD, McLachlan CS. Additional years of Australian rural clinical school undergraduate training is associated with rural practice. $B M C$ Medical Education 2013;13:1-9.

16. Kondalsamy-Chennakesavan S, Eley D, Ranmuthugala G, A C, Toombs M, Darshan $D$, et al. Determinants of rural practice: positive interaction between rural background and rural undergraduate training. Medical Journal of Australia 2015;202:41-5.

17. Kwan MMS, Kondalsamy-Chennakesavan S, Ranmuthugala G, Toombs MR, Nicholson GC. The rural pipeline to longer-term rural practice: General practitioners and specialists. PLOS ONE 2017;12:e0180394.

18. Worley P, Martin A, Prideaux D, Woodman R, Worley E, Lowe M. Vocational career paths of graduate entry medical students at Flinders University: a comparison of rural, remote and tertiary tracks. Medical Journal of Australia 2008;188:177-8.

19. Australian Bureau of Statistics. The Australian Statistical Geographical Classification (ASGC) Remoteness Structure. Canberra: ABS, 2006. http://www.abs.gov.au/websitedbs/d3310114.nsf/home/remoteness+structure \#Anchor2 (accessed.29 January 2018).

20. Jones MP, Bushnell JA, Humphreys JS. Are rural placements positively associated with rural intentions in medical graduates? Medical Education 2014;48:40516.

21. Russell DJ, Humphreys JS, McGrail MR, Cameron WI, Williams PJ. The value of survival analyses for evidence-based rural medical workforce planning. Human Resources for Health 2013;11:1-9.

22. Rabinowitz HK, Diamond JJ, Markham FW, Santana AJ. The relationship between entering medical students' backgrounds and career plans and their rural practice outcomes three decades later. Academic Medicine 2012;87:493-7. 
Table 1 Rural immersion opportunities during the medical degree, Monash University, Victoria, Australia

\begin{tabular}{|c|c|c|c|}
\hline $\begin{array}{l}\text { Stage of medical } \\
\text { degree course }\end{array}$ & Curriculum & $\begin{array}{l}\text { Rural opportunities (accessible on an opt-in } \\
\text { basis) }\end{array}$ & $\begin{array}{l}\text { Category for } \\
\text { analysis }\end{array}$ \\
\hline $\begin{array}{l}\text { Year } 1 \& 2 \text { for direct } \\
\text { entry students or years } \\
1 \& 2 \text { combined in a } \\
\text { single year for graduate } \\
\text { entry students }\end{array}$ & $\begin{array}{l}\text { Class-room based } \\
\text { learning: basic } \\
\text { biosciences }\end{array}$ & $\begin{array}{l}\text { - Typically several weeks only, non- } \\
\text { clinical }\end{array}$ & $\begin{array}{l}\text { Not included } \\
\text { in analyses of } \\
\text { duration and } \\
\text { setting }\end{array}$ \\
\hline Year 3 & $\begin{array}{l}\text { Foundation clinical } \\
\text { training: medicine \& } \\
\text { surgery }\end{array}$ & $\begin{array}{l}\text { - A whole year based in a hospital in a } \\
\text { regional centre }{ }^{\text {a }}\end{array}$ & $\begin{array}{l}\text { Regional } \\
\text { hospital }^{\text {a }}\end{array}$ \\
\hline \multirow[t]{2}{*}{ Year 4} & \multirow[t]{2}{*}{$\begin{array}{l}\text { Clinical skills } \\
\text { extension: general } \\
\text { practice, women's } \\
\text { health, psychiatry, } \\
\text { children's health. }\end{array}$} & $\begin{array}{l}\text { - Six months to a whole year based in a } \\
\text { hospital in a regional centre, with one } \\
\text { day per week in general practice in a } \\
\text { regional centre }{ }^{\text {a }} \text { or } \\
\text { - A whole year based in a hospital in } \\
\text { regional centre with alternate six- } \\
\text { weekly rotations between the hospital } \\
\text { and a general practice in the same } \\
\text { regional centre }{ }^{\text {a }}\end{array}$ & $\begin{array}{l}\text { Regional } \\
\text { hospital }^{\text {a }}\end{array}$ \\
\hline & & $\begin{array}{l}\text { - Six months based in a general practice } \\
\text { in a rural town, parallel consulting in a } \\
\text { small rural hospital with GPs }{ }^{\mathrm{b}} \text { or } \\
\text { - A whole year based in general practice } \\
\text { in a rural town, parallel consulting in a } \\
\text { small rural hospital and undertaking } \\
\text { one day per week for selected curricula } \\
\text { (women's health and psychiatry), in a } \\
\text { small rural hospital }{ }^{\mathrm{b}}\end{array}$ & $\begin{array}{l}\text { Rural general } \\
\text { practice }^{\mathrm{b}}\end{array}$ \\
\hline Year 5 & $\begin{array}{l}\text { Pre-intern year: acute } \\
\text { care, medicine, } \\
\text { surgery, aged care, } \\
\text { specialty, elective. }\end{array}$ & $\begin{array}{l}\text { - Six, six-week clinical rotations, mostly } \\
\text { based in a hospital in various regional } \\
\text { centres }^{\text {a }}\end{array}$ & $\begin{array}{l}\text { Regional } \\
\text { hospital }^{\text {a }}\end{array}$ \\
\hline
\end{tabular}

a Regional locations included: Mildura, Bendigo, Traralgon, Warragul, Sale. Most regional centres have 15,000+ population and are located within a few hours' travel from the nearest metropolitan city, Melbourne, except Mildura located $>500 \mathrm{~km}$ from Melbourne and accessible by a one-hour flight.

b Rural town locations included: Woodend, Kyneton, Gisborne, Castlemaine, Maryborough, Swan Hill, Bairnsdale, Sale, Lakes Entrance, Orbost, Maffra, Heyfield, Foster, Korumburra, Leongatha, Wonthaggi. Most rural towns have 
$<15,000$ population and are located between one and four hours' drive from the nearest metropolitan city, Melbourne.

Table 2: Univariate (unadjusted) associations between student characteristics, duration and setting of rural immersion and rural work location in 2017, (Doctors in this study were in postgraduate year 1 to $9 ; n=2412$ )

\begin{tabular}{|c|c|c|c|c|c|c|}
\hline Characteristic & Group & $\begin{array}{l}\text { Count - } \\
\text { working in } \\
2017\end{array}$ & $\begin{array}{l}\text { Propor- } \\
\text { tion (\%) }\end{array}$ & $\begin{array}{l}\text { Count - } \\
\text { working } \\
\text { rural in } 2017\end{array}$ & $\begin{array}{l}\text { \% working } \\
\text { rural } 2017\end{array}$ & $\begin{array}{l}\mathrm{p}- \\
\text { value }\end{array}$ \\
\hline \multirow{4}{*}{$\begin{array}{l}\text { Age at course entry } \\
\text { (years) }\end{array}$} & $<=19$ & 1555 & 64.5 & 164 & 10.6 & $<0.001$ \\
\hline & $20-21$ & 440 & 18.3 & 81 & 18.4 & \\
\hline & $22-24$ & 238 & 9.9 & 44 & 18.5 & \\
\hline & $25+$ & 178 & 7.4 & 48 & 27.0 & \\
\hline \multirow[t]{2}{*}{ Gender } & Male & 1098 & 45.5 & 138 & 12.6 & 0.08 \\
\hline & Female & 1313 & 54.5 & 199 & 15.2 & \\
\hline \multirow{2}{*}{ Rural background } & No & 1888 & 78.3 & 177 & 9.4 & $<0.001$ \\
\hline & Yes & 523 & 21.7 & 160 & 30.6 & \\
\hline \multirow{2}{*}{$\begin{array}{l}\text { International student } \\
\text { status }\end{array}$} & Domestic & 2126 & 88.1 & 273 & 12.8 & $<0.001$ \\
\hline & International & 286 & 11.9 & 64 & 22.4 & \\
\hline \multirow{2}{*}{ Either BMP / MRBS ${ }^{\text {a }}$} & No & 1946 & 80.7 & 258 & 13.3 & 0.044 \\
\hline & Yes & 466 & 19.3 & 79 & 17.0 & \\
\hline \multirow[t]{2}{*}{$\mathrm{BMP}^{\mathrm{a}}$} & No & 1905 & 79.0 & 238 & 12.5 & $<0.001$ \\
\hline & Yes & 507 & 21.0 & 99 & 19.5 & \\
\hline \multirow[t]{2}{*}{ MRBS $^{a}$} & No & 2371 & 98.3 & 317 & 13.4 & $<0.001$ \\
\hline & Yes & 41 & 1.7 & 20 & 48.8 & \\
\hline \multirow[t]{2}{*}{ Graduate entry } & Direct entry & 1998 & 82.8 & 248 & 12.4 & $<0.001$ \\
\hline & Graduate entry & 414 & 17.2 & 89 & 21.5 & \\
\hline \multirow{3}{*}{$\begin{array}{l}\text { Interest in working in } \\
\text { a rural area }\end{array}$} & No & 1226 & 50.8 & 114 & 9.3 & $<0.001$ \\
\hline & Yes & 347 & 14.4 & 93 & 26.8 & \\
\hline & Unknown & 839 & 34.8 & 130 & 15.5 & \\
\hline \multirow{3}{*}{$\begin{array}{l}\text { Interest in becoming a } \\
\text { general practitioner } \\
(\text { top } 3)^{a}\end{array}$} & No & 948 & 39.3 & 114 & 12.0 & 0.002 \\
\hline & Yes & 361 & 15.0 & 71 & 19.7 & \\
\hline & Unknown & 1103 & 45.7 & 152 & 13.8 & \\
\hline \multirow[t]{5}{*}{ Duration (years 3 to 5) } & $\begin{array}{l}\text { Nil (including 0-6 } \\
\text { weeks rural) }\end{array}$ & 1412 & 58.5 & 123 & 8.7 & $<0.001$ \\
\hline & Less than one year & 226 & 9.4 & 24 & 10.6 & \\
\hline & One full year & 226 & 9.4 & 34 & 15.0 & \\
\hline & Between 1 and 2 years & 298 & 12.4 & 58 & 19.5 & \\
\hline & More than 2 (up to 3 & 250 & 10.4 & 98 & 39.2 & \\
\hline
\end{tabular}




\begin{tabular}{|c|c|c|c|c|c|c|c|}
\hline & \multicolumn{2}{|l|}{ years) } & & & & & \\
\hline \multirow[t]{3}{*}{ Setting (years 3 to 5 ) } & \multicolumn{2}{|l|}{ No rural } & 1412 & 58.5 & 123 & 8.7 & $<0.001$ \\
\hline & \multicolumn{2}{|c|}{ Regional hospital only } & 515 & 21.4 & 89 & 17.3 & \\
\hline & \multicolumn{2}{|c|}{$\begin{array}{l}\text { Rural general practice } \\
\text { only }\end{array}$} & 118 & 4.9 & 16 & 13.6 & \\
\hline r & \multicolumn{2}{|l|}{ Both } & 367 & 15.2 & 109 & 29.7 & \\
\hline \multirow{8}{*}{$\begin{array}{l}\text { Duration \& setting } \\
\text { (years } 3 \text { to } 5 \text { ) }\end{array}$} & \multirow{2}{*}{\multicolumn{2}{|c|}{$\begin{array}{l}\text { Metropolitan only } \\
\text { (including 0-6 weeks } \\
\text { rural) }\end{array}$}} & 1412 & 58.5 & 123 & 8.7 & $<0.001$ \\
\hline & & & & & & & \\
\hline & \multirow[t]{2}{*}{$\begin{array}{l}\text { Regional } \\
\text { hospital only }\end{array}$} & $\begin{array}{l}\text { Up to } \\
\text { one year }\end{array}$ & 298 & 12.4 & 40 & 13.4 & \\
\hline & & $>1$ year & 217 & 9.0 & 49 & 22.6 & \\
\hline & \multirow[t]{2}{*}{$\begin{array}{l}\text { Rural general } \\
\text { practice only }\end{array}$} & $\begin{array}{l}\text { Up to } \\
\text { one year }\end{array}$ & 79 & 3.3 & 7 & 8.9 & \\
\hline & & $>1$ year & 39 & 1.6 & 9 & 23.1 & \\
\hline & \multirow[t]{2}{*}{ Both } & $\begin{array}{l}\text { Up to } \\
\text { one year }\end{array}$ & 75 & 3.1 & 11 & 14.7 & \\
\hline & & $>1$ year & 292 & 12.1 & 98 & 33.6 & \\
\hline \multirow{9}{*}{$\begin{array}{l}\text { Postgraduate year } \\
\text { (PGY) in } 2017\end{array}$} & \multicolumn{2}{|l|}{ PGY1 } & 363 & 15.1 & 68 & 18.7 & $<0.001$ \\
\hline & \multicolumn{2}{|l|}{ PGY2 } & 368 & 15.3 & 54 & 14.7 & \\
\hline & \multicolumn{2}{|l|}{ PGY3 } & 296 & 12.3 & 40 & 13.5 & \\
\hline & \multicolumn{2}{|l|}{ PGY4 } & 319 & 13.2 & 50 & 15.7 & \\
\hline & \multicolumn{2}{|l|}{ PGY5 } & 314 & 13.0 & 33 & 10.5 & \\
\hline & \multicolumn{2}{|l|}{ PGY6 } & 239 & 9.9 & 31 & 13.0 & \\
\hline & \multicolumn{2}{|l|}{ PGY7 } & 218 & 9.0 & 18 & 8.3 & \\
\hline & \multicolumn{2}{|l|}{ PGY8 } & 190 & 7.9 & 31 & 16.3 & \\
\hline & \multicolumn{2}{|l|}{ PGY9 } & 105 & 4.4 & 12 & 11.4 & \\
\hline \multirow[t]{4}{*}{ PGY stage 4 groups } & \multicolumn{2}{|l|}{ PGY 1-2 } & 731 & 30.3 & 122 & 16.7 & 0.03 \\
\hline & \multicolumn{2}{|l|}{ PGY 3-4 } & 615 & 25.5 & 90 & 14.6 & \\
\hline & \multicolumn{2}{|l|}{ PGY 5-6 } & 553 & 22.9 & 64 & 11.6 & \\
\hline & \multicolumn{2}{|l|}{ PGY 7+ } & 513 & 21.3 & 61 & 11.9 & \\
\hline
\end{tabular}

a Bonded Medical Places (BMP) and Medical Rural Bonded Scholarship (MRBS) Schemes commenced in 2004 and 2001 respectively. Students self-nominate to participate in these Schemes. Up until 2016, the BMP required students (approximately $25 \%$ of all students enrolled in medicine in Australia), once they graduate, to work in rural areas of workforce shortage for a term equivalent to the term of their degree (typically four years). The rural term of work required was reduced to one year for students starting the medical course on a BMP from 2016 onwards. The benefit for students is increased likelihood of getting a place in the medical course. The MRBS offered students around $\$ 26,000$ per financial year for agreeing they would work in rural areas for 6 years after they were specialistqualified [11]. It ceased for students entering medicine in 2016.

${ }^{\mathrm{b}}$ Medical Student Outcomes Database (MSOD) data could not be linked for 2004 and 2005 commencement cohorts $(\mathrm{N}=369)$. Around $83 \%$ of the remaining cohorts were successfully matched; however there were $8 \%$ and $23 \%$ 
missing responses for the location and specialty preference questions respectively. The questions used from the MSOD survey, administered to all cohorts at the commencement of the medical course, were: 1) On completing of your basic medical degree, where would you most like to practise medicine? Please indicate in which geographical location in Australia (categorised as 'metropolitan': capital city; major urban centre >100,000 population; or 'rural': regional city or large town 25-100,000 population, smaller town 10-24,999 population, small rural community $<10,000$ population). And 2) When you have completed your basic medical degree, what area of medicine are you most interested in pursuing? (One response only categorised as: 'general practice' or 'not': other specialty (as listed), not yet decided, other specialty, as specified)

Table 3: Multiple logistic regression models and odds ratios (OR) of associations between rural immersion duration and setting and working in any rural area in 2017 (Doctors in this study were in postgraduate year 1 to $9 ; n=2412$ )

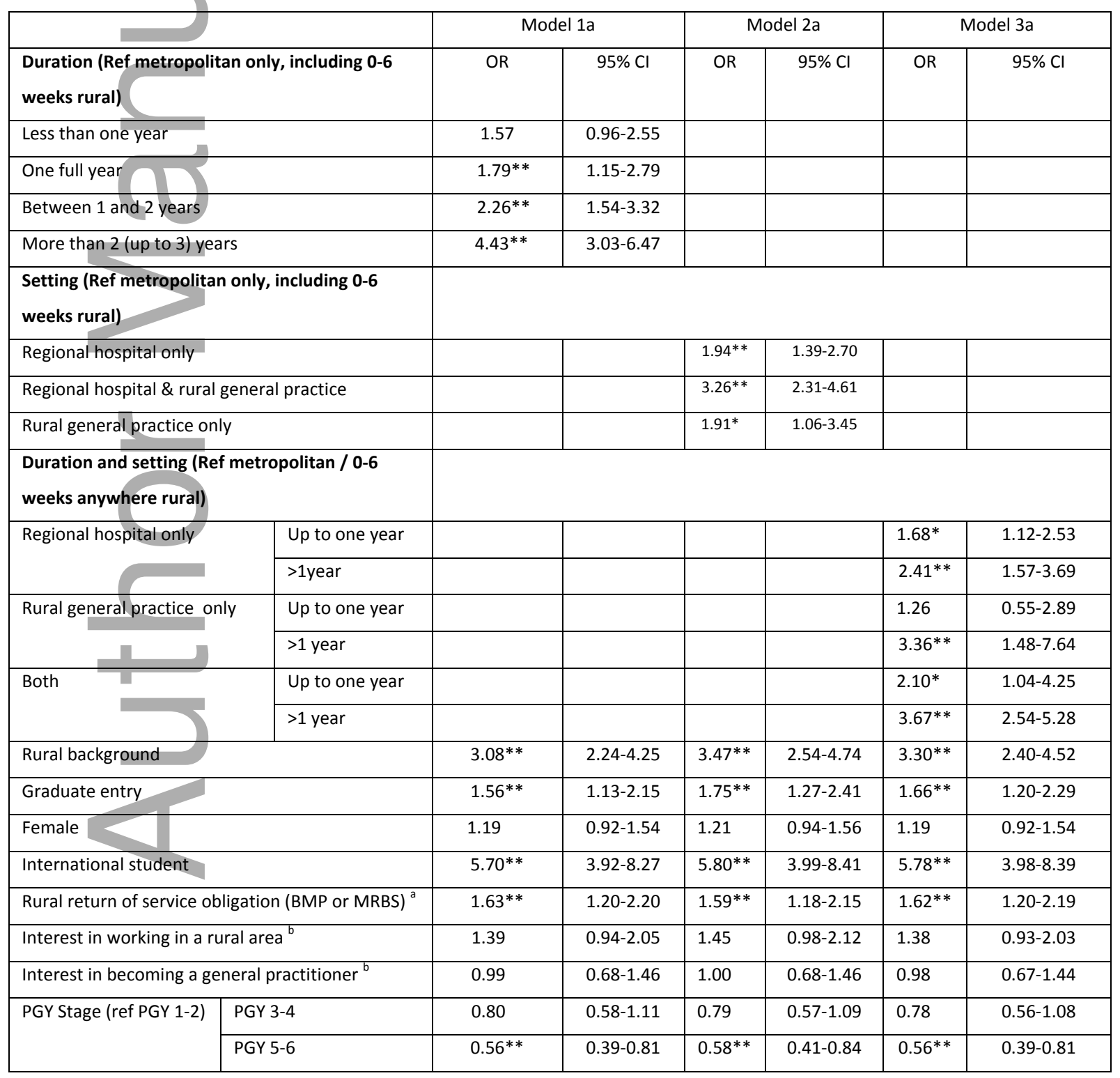

This article is protected by copyright. All rights reserved 


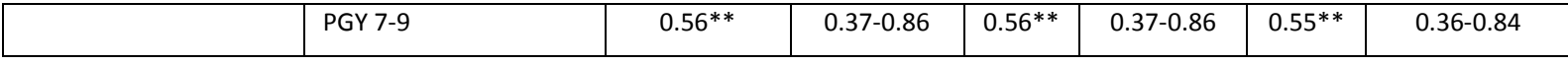

a. $* *=\mathrm{P}<0.01 ; *=\mathrm{P}<0.05$

${ }^{\text {a }}$ Students on Bonded Medical Places (BMP) or Medical Rural Bonded Scholarships (MRBS) were included as one category as they were equally significant in univariate analysis. The rural requirements of these Schemes are outlined in Table 2, footnote ${ }^{b}$.

${ }^{b}$ Based on questions in the Medical Students Outcomes Database survey, administered at the commencement of the medical course asking students: On completing your basic medical degree, where would you most like to practise medicine?; What area of medicine are you most interested in pursuing?

Table 4: Multinomial logit regression models and relative risk ratios (RRR) of associations between rural immersion duration and setting and working in large or smaller regional centres or rural towns ${ }^{\mathrm{a}}$ in 2017, (Doctors in this study were in postgraduate year (PGY) 1 to 9; $n=2412$ )

\begin{tabular}{|c|c|c|c|c|c|c|c|c|c|c|c|c|}
\hline & \multicolumn{4}{|c|}{ Model 1b } & \multicolumn{4}{|c|}{ Model 2b } & \multicolumn{4}{|c|}{ Model 3b } \\
\hline & \multicolumn{2}{|c|}{$\begin{array}{l}\text { Large regional } \\
\text { centre }\end{array}$} & \multicolumn{2}{|c|}{$\begin{array}{l}\text { Smaller } \\
\text { regional/rural } \\
\text { town }\end{array}$} & \multicolumn{2}{|c|}{$\begin{array}{l}\text { Large regional } \\
\text { centre }\end{array}$} & \multicolumn{2}{|c|}{$\begin{array}{l}\text { Smaller } \\
\text { regional/rural } \\
\text { town }\end{array}$} & \multicolumn{2}{|c|}{$\begin{array}{l}\text { Large regional } \\
\text { centre }\end{array}$} & \multicolumn{2}{|c|}{$\begin{array}{l}\text { Smaller } \\
\text { regional/rural } \\
\text { town }\end{array}$} \\
\hline & RRR & $\begin{array}{l}95 \% \\
\mathrm{Cl}\end{array}$ & & $\begin{array}{l}95 \% \\
\mathrm{Cl}\end{array}$ & RRR & $\begin{array}{l}95 \% \\
\mathrm{Cl}\end{array}$ & & $\begin{array}{l}95 \% \\
\mathrm{Cl}\end{array}$ & RRR & $\begin{array}{l}95 \% \\
\mathrm{Cl}\end{array}$ & RRR & $\begin{array}{l}95 \% \\
\mathrm{Cl}\end{array}$ \\
\hline $\begin{array}{l}\text { Duration (Ref 0-6 } \\
\text { wk) }\end{array}$ & & & & & & & & & & & & \\
\hline Less than 1 year & 1.77 & $\begin{array}{l}0.94- \\
3.32\end{array}$ & 1.35 & $\begin{array}{l}0.66- \\
2.73\end{array}$ & & & & & & & & \\
\hline One full year & $2.11^{*}$ & $\begin{array}{l}1.17- \\
3.82\end{array}$ & 1.53 & $\begin{array}{l}0.85- \\
2.76\end{array}$ & & & & & & & & \\
\hline $\begin{array}{l}\text { Between } 1 \text { and } 2 \\
\text { years }\end{array}$ & $1.98^{*}$ & $\begin{array}{l}1.13- \\
3.46\end{array}$ & $2.44^{* *}$ & $\begin{array}{l}1.51- \\
3.94\end{array}$ & & & & & & & & \\
\hline $\begin{array}{l}\text { More than } 2 \text { (up to } \\
\text { 3) years }\end{array}$ & $5.77^{* *}$ & $\begin{array}{l}3.51- \\
9.49\end{array}$ & $3.34^{* *}$ & $\begin{array}{l}2.02- \\
5.52\end{array}$ & & & & & & & & \\
\hline $\begin{array}{l}\text { Setting (Ref metro } \\
\text { only, i.e. 0-6 weeks) }\end{array}$ & & & & & & & & & & & & \\
\hline $\begin{array}{l}\text { Regional hospital } \\
\text { only }\end{array}$ & & & & & $2.34^{* *}$ & $\begin{array}{l}1.50- \\
3.66\end{array}$ & $1.80 * *$ & $\begin{array}{l}1.17- \\
2.78\end{array}$ & & & & \\
\hline $\begin{array}{l}\text { Rural general } \\
\text { practice only }\end{array}$ & & & & & 1.06 & $\begin{array}{l}0.37- \\
3.05\end{array}$ & 1.92 & $\begin{array}{l}0.89- \\
4.14\end{array}$ & & & & \\
\hline Both & & & & & $3.72 * *$ & $\begin{array}{l}2.35- \\
5.87\end{array}$ & $2.73 * *$ & $\begin{array}{l}1.72- \\
4.32\end{array}$ & & & & \\
\hline $\begin{array}{l}\text { Duration and setting } \\
\text { (Ref metro / 0-6 } \\
\text { weeks) }\end{array}$ & & & & & & & & & & & & \\
\hline
\end{tabular}




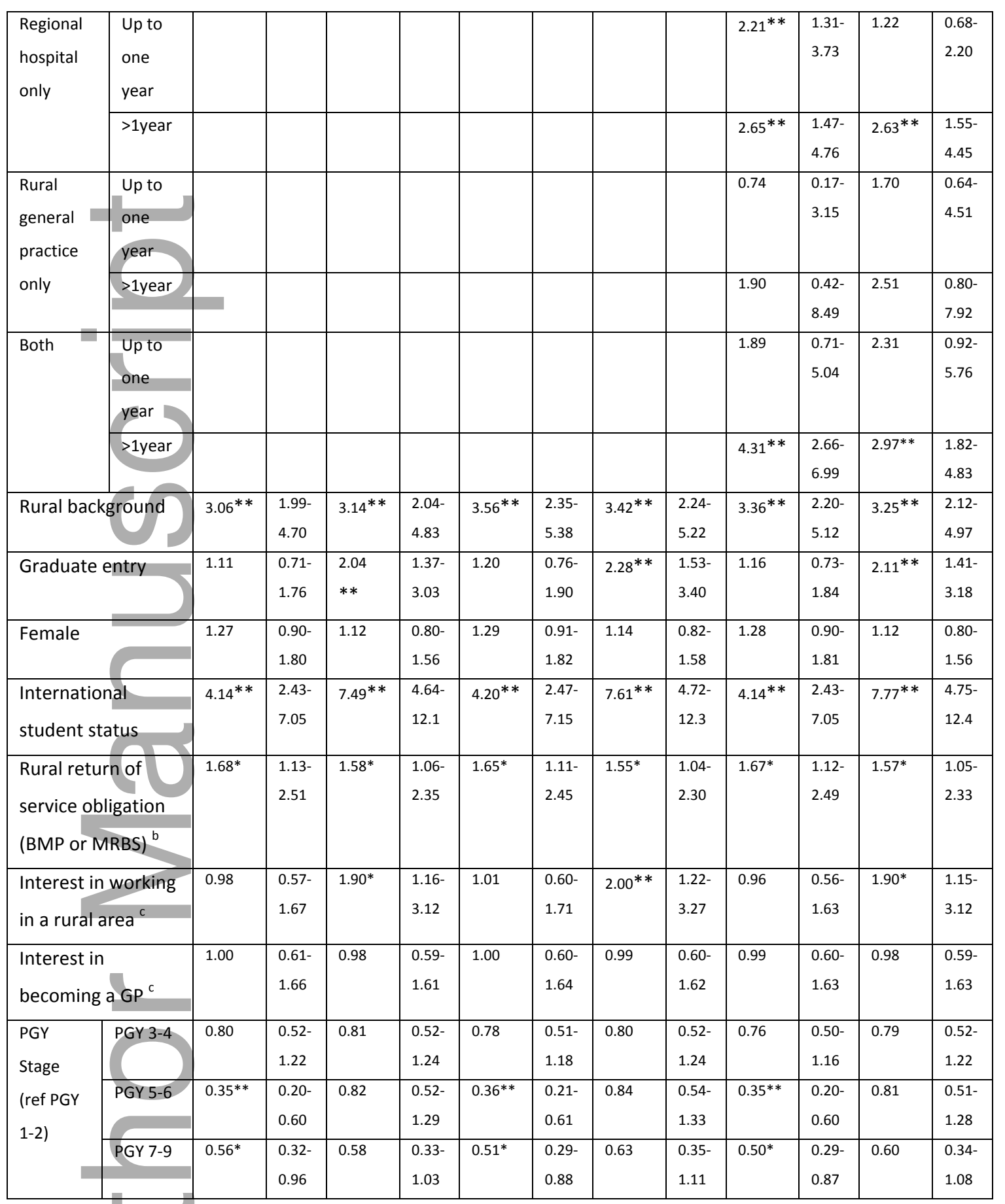

${ }^{* *}=\mathrm{P}<0.01 ;{ }^{*}=\mathrm{P}<0.05 ; \mathrm{GP}=$ General Practitioner

a Based on the Modified Monash Model 'large region' is MMM2 $=\geq 50,000$ population and 'smaller region/rural town' is $M M M 3$ to $7<50,000$ population

${ }^{\mathrm{b}}$ Students on Bonded Medical Places (BMP) or Medical Rural Bonded Scholarships (MRBS) were included as one category as they were equally significant in univariate analysis

${ }^{\mathrm{c}}$ Based on questions in the Medical Students Outcomes Database survey, administered at the commencement of the medical course asking students: On completing your basic medical degree, where would you most like to practise medicine?; What area of medicine are you most interested in pursuing? 
Figure 1: Proportion of students working in rural locations in 2017 by rural-background and duration and setting of rural immersion

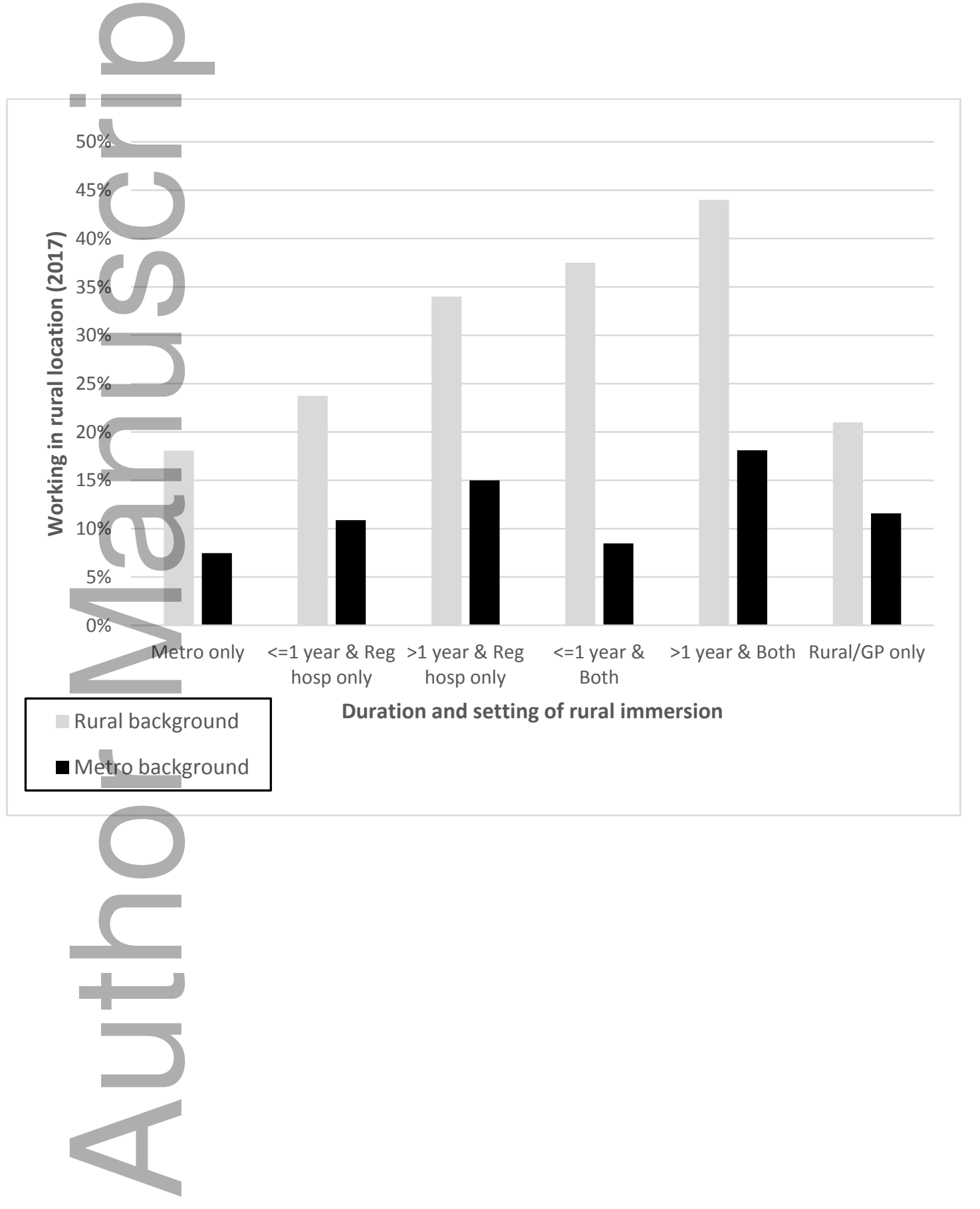


Table 1 Rural immersion opportunities during the medical degree, Monash University, Victoria, Australia

\begin{tabular}{|c|c|c|c|}
\hline $\begin{array}{l}\text { Stage of medical } \\
\text { degree course }\end{array}$ & Curriculum & $\begin{array}{l}\text { Rural opportunities (accessible on an opt-in } \\
\text { basis) }\end{array}$ & $\begin{array}{l}\text { Category for } \\
\text { analysis }\end{array}$ \\
\hline $\begin{array}{l}\text { Year } 1 \& 2 \text { for direct } \\
\text { entry students or years } \\
1 \& 2 \text { combined in a } \\
\text { single year for graduate } \\
\text { entry students }\end{array}$ & $\begin{array}{l}\text { Class-room based } \\
\text { learning: basic } \\
\text { biosciences }\end{array}$ & $\begin{array}{l}\text { - Typically several weeks only, non- } \\
\text { clinical }\end{array}$ & $\begin{array}{l}\text { Not included } \\
\text { in analyses of } \\
\text { duration and } \\
\text { setting }\end{array}$ \\
\hline Year 3 & $\begin{array}{l}\text { Foundation clinical } \\
\text { training: medicine \& } \\
\text { surgery }\end{array}$ & $\begin{array}{l}\text { - A whole year based in a hospital in a } \\
\text { regional centre }{ }^{\text {a }}\end{array}$ & $\begin{array}{l}\text { Regional } \\
\text { hospital }^{\text {a }}\end{array}$ \\
\hline \multirow[t]{2}{*}{ Year 4} & \multirow[t]{2}{*}{$\begin{array}{l}\text { Clinical skills } \\
\text { extension: general } \\
\text { practice, women's } \\
\text { health, psychiatry, } \\
\text { children's health. }\end{array}$} & $\begin{array}{l}\text { - Six months to a whole year based in a } \\
\text { hospital in a regional centre, with one } \\
\text { day per week in general practice in a } \\
\text { regional centre or } \\
\text { A whole year based in a hospital in } \\
\text { regional centre with alternate six- } \\
\text { weekly rotations between the hospital } \\
\text { and a general practice in the same } \\
\text { regional centre }{ }^{\text {a }}\end{array}$ & $\begin{array}{l}\text { Regional } \\
\text { hospital }^{\text {a }}\end{array}$ \\
\hline & & $\begin{array}{l}\text { - Six months based in a general practice } \\
\text { in a rural town, parallel consulting in a } \\
\text { small rural hospital with GPs }{ }^{\text {b }} \text { or } \\
\text { - A whole year based in general practice } \\
\text { in a rural town, parallel consulting in a } \\
\text { small rural hospital and undertaking } \\
\text { one day per week for selected curricula } \\
\text { (women's health and psychiatry), in a } \\
\text { small rural hospital }{ }^{\text {b }}\end{array}$ & $\begin{array}{l}\text { Rural general } \\
\text { practice }^{b}\end{array}$ \\
\hline Year 5 & $\begin{array}{l}\text { Pre-intern year: acute } \\
\text { care, medicine, } \\
\text { surgery, aged care, } \\
\text { specialty, elective. }\end{array}$ & $\begin{array}{l}\text { - Six, six-week clinical rotations, mostly } \\
\text { based in a hospital in various regional } \\
\text { centres }^{\text {a }}\end{array}$ & $\begin{array}{l}\text { Regional } \\
\text { hospital }^{\text {a }}\end{array}$ \\
\hline
\end{tabular}

a Regional locations included: Mildura, Bendigo, Traralgon, Warragul, Sale. Most regional centres have 15,000+ population and are located within a few hours' travel from the nearest metropolitan city, Melbourne, except Mildura located $>500 \mathrm{~km}$ from Melbourne and accessible by a one-hour flight.

b Rural town locations included: Woodend, Kyneton, Gisborne, Castlemaine, Maryborough, Swan Hill, Bairnsdale, Sale, Lakes Entrance, Orbost, Maffra, Heyfield, Foster, Korumburra, Leongatha, Wonthaggi. Most rural towns have $<15,000$ population and are located between one and four hours' drive from the nearest metropolitan city, Melbourne.

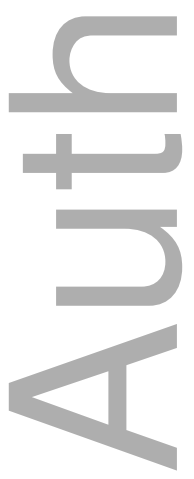


Table 2: Univariate (unadjusted) associations between student characteristics, duration and setting of rural immersion and rural work location in 2017, (Doctors in this study were in postgraduate year 1 to $9 ; n=2412$ )

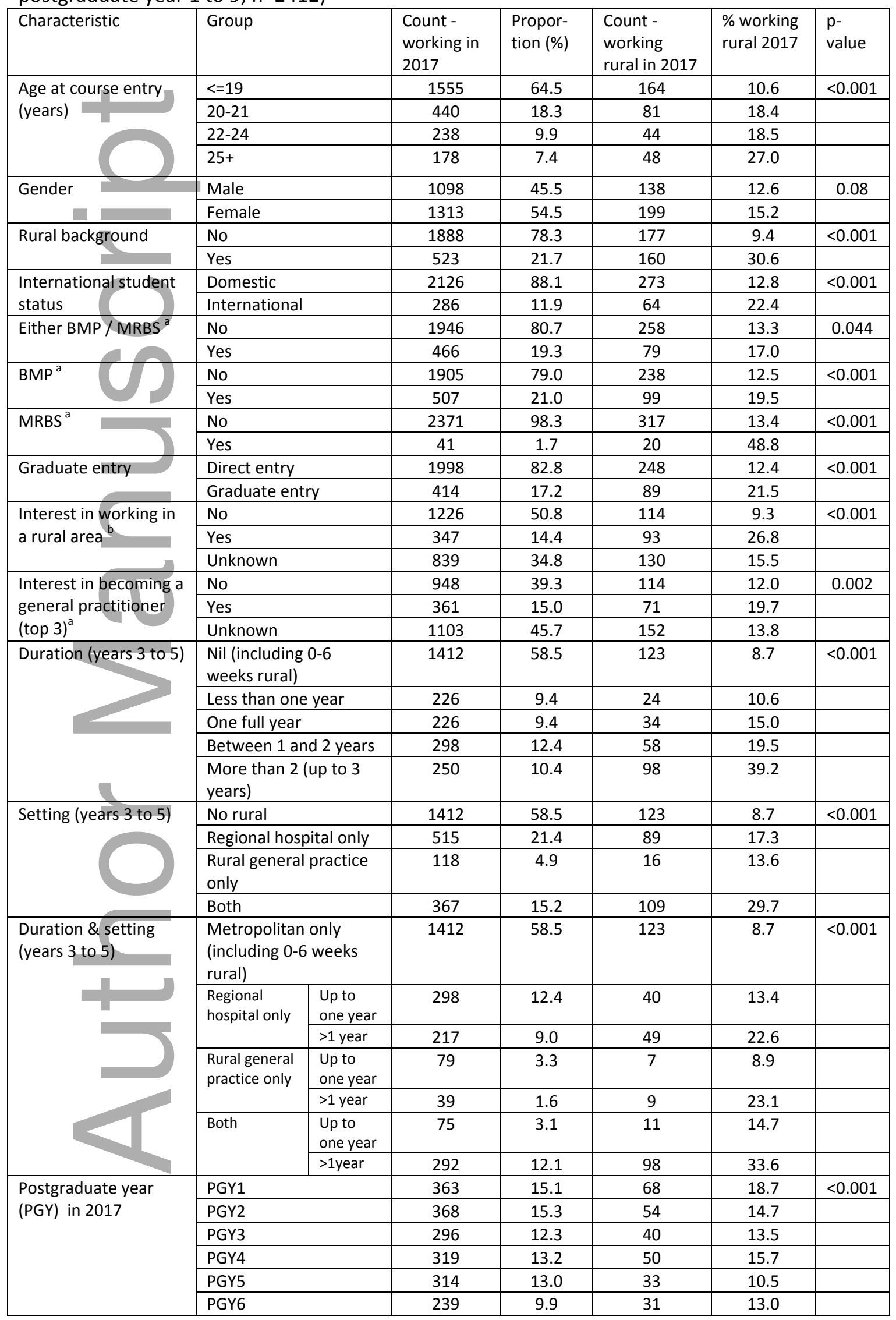




\begin{tabular}{|l|l|c|c|c|c|c|}
\hline & PGY7 & 218 & 9.0 & 18 & 8.3 & \\
\cline { 2 - 7 } & PGY8 & 190 & 7.9 & 31 & 16.3 & \\
\cline { 2 - 7 } & PGY9 & 105 & 4.4 & 12 & 11.4 & \\
\hline \multirow{5}{*}{ PGY stage 4 groups } & PGY 1-2 & 731 & 30.3 & 122 & 16.7 & 0.03 \\
\cline { 2 - 7 } & PGY 3-4 & 615 & 25.5 & 90 & 14.6 & \\
\cline { 2 - 7 } & PGY 5-6 & 553 & 22.9 & 64 & 11.6 & \\
\cline { 2 - 7 } & PGY 7+ & 513 & 21.3 & 61 & 11.9 & \\
\hline
\end{tabular}

a Bonded Medical Places (BMP) and Medical Rural Bonded Scholarship (MRBS) Schemes commenced in 2004 and 2001 respectively. Students self-nominate to participate in these Schemes. Up until 2016, the BMP required students (approximately $25 \%$ of all students enrolled in medicine in Australia), once they graduate, to work in rural areas of workforce shortage for a term equivalent to the term of their degree (typically four years). The rural term of work required was reduced to one year for students starting the medical course on a BMP from 2016 onwards. The benefit for students is increased likelihood of getting a place in the medical course. The MRBS offered students around $\$ 26,000$ per financial year for agreeing they would work in rural areas for 6 years after they were specialistqualified [11]. It ceased for students entering medicine in 2016.

${ }^{\mathrm{b}}$ Medical Student Outcomes Database (MSOD) data could not be linked for 2004 and 2005 commencement cohorts $(\mathrm{N}=369)$. Around $83 \%$ of the remaining cohorts were successfully matched; however there were $8 \%$ and $23 \%$ missing responses for the location and specialty preference questions respectively. The questions used from the MSOD survey, administered to all cohorts at the commencement of the medical course, were: 1) On completing of your basic medical degree, where would you most like to practise medicine? Please indicate in which geographical location in Australia (categorised as 'metropolitan': capital city; major urban centre >100,000 population; or 'rural': regional city or large town 25-100,000 population, smaller town 10-24,999 population, small rural community $<10,000$ population). And 2) When you have completed your basic medical degree, what area of medicine are you most interested in pursuing? (One response only categorised as: 'general practice' or 'not': other specialty (as listed), not yet decided, other specialty, as specified)

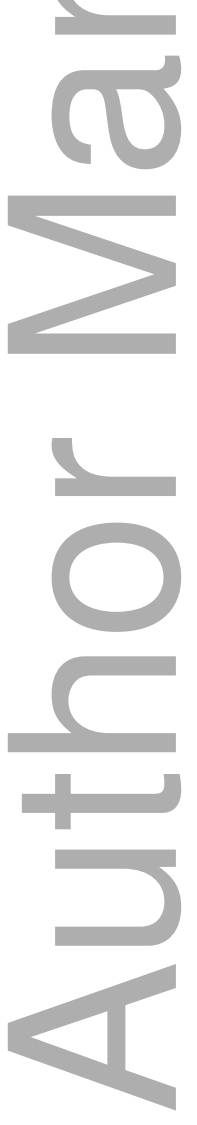


Table 3: Multiple logistic regression models and odds ratios (OR) of associations between rural immersion duration and setting and working in any rural area in 2017 (Doctors in this study were in postgraduate year 1 to $9 ; n=2412$ )

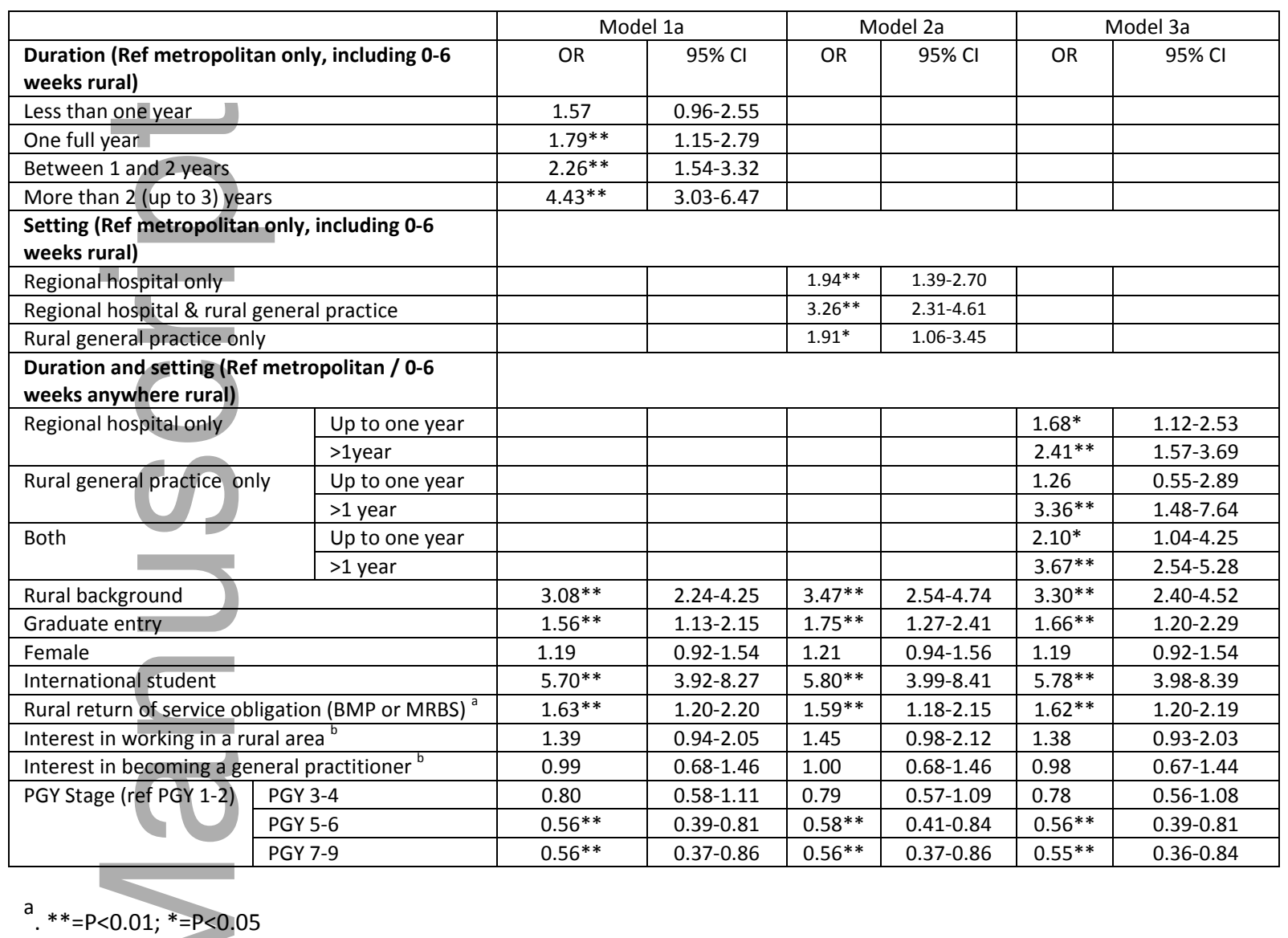

a Students on Bonded Medical Places (BMP) or Medical Rural Bonded Scholarships (MRBS) were included as one category as they were equally significant in univariate analysis. The rural requirements of these Schemes are outlined in Table 2, footnote ${ }^{b}$.

${ }^{b}$ Based on questions in the Medical Students Outcomes Database survey, administered at the commencement of the medical course asking students: On completing your basic medical degree, where would you most like to practise medicine?; What area of medicine are you most interested in pursuing? 
Table 4: Multinomial logit regression models and relative risk ratios (RRR) of associations between rural immersion duration and setting and working in large or smaller regional centres or rural towns ${ }^{\mathrm{a}}$ in 2017 , (Doctors in this study were in postgraduate year (PGY) 1 to 9; $n=2412$ )

\begin{tabular}{|c|c|c|c|c|c|c|c|c|c|c|c|c|c|}
\hline & & \multicolumn{4}{|c|}{ Model 1b } & \multicolumn{4}{|c|}{ Model 2b } & \multicolumn{4}{|c|}{ Model 3b } \\
\hline & & \multicolumn{2}{|c|}{$\begin{array}{l}\text { Large regional } \\
\text { centre }\end{array}$} & \multicolumn{2}{|c|}{$\begin{array}{l}\text { Smaller } \\
\text { regional/rural } \\
\text { town }\end{array}$} & \multicolumn{2}{|c|}{$\begin{array}{l}\text { Large regional } \\
\text { centre }\end{array}$} & \multicolumn{2}{|c|}{$\begin{array}{l}\text { Smaller } \\
\text { regional/rural } \\
\text { town }\end{array}$} & \multicolumn{2}{|c|}{$\begin{array}{l}\text { Large regional } \\
\text { centre }\end{array}$} & \multicolumn{2}{|c|}{$\begin{array}{l}\text { Smaller } \\
\text { regional/rural } \\
\text { town }\end{array}$} \\
\hline & & RRR & $\begin{array}{l}95 \% \\
\mathrm{Cl}\end{array}$ & & $\begin{array}{l}95 \% \\
\mathrm{Cl}\end{array}$ & RRR & $\begin{array}{l}95 \% \\
\mathrm{Cl}\end{array}$ & & $\begin{array}{l}95 \% \\
\mathrm{Cl}\end{array}$ & RRR & $\begin{array}{l}95 \% \\
\mathrm{Cl}\end{array}$ & RRR & $\begin{array}{l}95 \% \\
\mathrm{Cl}\end{array}$ \\
\hline \multicolumn{14}{|c|}{$\begin{array}{l}\text { Duration (Ref 0-6 } \\
\text { wk) }\end{array}$} \\
\hline Less tha & year & 1.77 & $\begin{array}{l}0.94- \\
3.32\end{array}$ & 1.35 & $\begin{array}{l}0.66- \\
2.73\end{array}$ & & & & & & & & \\
\hline One full & ar & $2.11^{*}$ & $\begin{array}{l}1.17- \\
3.82\end{array}$ & 1.53 & $\begin{array}{l}0.85- \\
2.76\end{array}$ & & & & & & & & \\
\hline $\begin{array}{l}\text { Betweer } \\
\text { years }\end{array}$ & and 2 & $1.98^{*}$ & $\begin{array}{l}1.13- \\
3.46\end{array}$ & $2.44^{* *}$ & $\begin{array}{l}1.51- \\
3.94\end{array}$ & & & & & & & & \\
\hline $\begin{array}{l}\text { More th } \\
\text { 3) years }\end{array}$ & 2 (up to & $5.77^{* *}$ & $\begin{array}{l}3.51- \\
9.49\end{array}$ & $3.34 * *$ & $\begin{array}{l}2.02- \\
5.52\end{array}$ & & & & & & & & \\
\hline \multicolumn{14}{|c|}{$\begin{array}{l}\text { Setting (Ref metro } \\
\text { only, i.e. 0-6 weeks) }\end{array}$} \\
\hline $\begin{array}{l}\text { Regiona } \\
\text { only }\end{array}$ & ospital & & & & & $2.34 * *$ & $\begin{array}{l}1.50- \\
3.66\end{array}$ & $1.80 * *$ & $\begin{array}{l}1.17- \\
2.78\end{array}$ & & & & \\
\hline $\begin{array}{l}\text { Rural ge } \\
\text { practice }\end{array}$ & $\begin{array}{l}\text { al } \\
\text { ly }\end{array}$ & & & & & 1.06 & $\begin{array}{l}0.37- \\
3.05\end{array}$ & 1.92 & $\begin{array}{l}0.89- \\
4.14\end{array}$ & & & & \\
\hline Both & & & & & & $3.72 * *$ & $\begin{array}{l}2.35- \\
5.87\end{array}$ & $2.73 * *$ & $\begin{array}{l}1.72- \\
4.32\end{array}$ & & & & \\
\hline \multicolumn{14}{|c|}{$\begin{array}{l}\text { Duration and setting } \\
\text { (Ref metro / 0-6 } \\
\text { weeks) }\end{array}$} \\
\hline \multirow[t]{2}{*}{$\begin{array}{l}\text { Regional } \\
\text { hospital } \\
\text { only }\end{array}$} & $\begin{array}{l}\text { Up to } \\
\text { one } \\
\text { year } \\
\end{array}$ & & & & & & & & & $2.21^{* *}$ & $\begin{array}{l}1.31- \\
3.73\end{array}$ & 1.22 & $\begin{array}{l}0.68- \\
2.20\end{array}$ \\
\hline & $>1$ year & & & & & & & & & $2.65 * *$ & $\begin{array}{l}1.47- \\
4.76 \\
\end{array}$ & $2.63^{* *}$ & $\begin{array}{l}1.55- \\
4.45 \\
\end{array}$ \\
\hline \multirow{2}{*}{$\begin{array}{l}\text { Rural } \\
\text { general } \\
\text { practice } \\
\text { only }\end{array}$} & $\begin{array}{l}\text { Up to } \\
\text { one } \\
\text { year }\end{array}$ & & & & & & & & & 0.74 & $\begin{array}{l}0.17- \\
3.15\end{array}$ & 1.70 & $\begin{array}{l}0.64- \\
4.51\end{array}$ \\
\hline & >1year & & & & & & & & & 1.90 & $\begin{array}{l}0.42- \\
8.49 \\
\end{array}$ & 2.51 & $\begin{array}{l}0.80- \\
7.92 \\
\end{array}$ \\
\hline \multirow[t]{2}{*}{ Both } & $\begin{array}{l}\text { Up to } \\
\text { one } \\
\text { year }\end{array}$ & & & & & & & & & 1.89 & $\begin{array}{l}0.71- \\
5.04\end{array}$ & 2.31 & $\begin{array}{l}0.92- \\
5.76\end{array}$ \\
\hline & >1year & & & & & & & & & $4.31 * *$ & $\begin{array}{l}2.66- \\
6.99\end{array}$ & $2.97 * *$ & $\begin{array}{l}1.82- \\
4.83\end{array}$ \\
\hline \multicolumn{2}{|c|}{ Rural background } & $3.06 * *$ & $\begin{array}{l}1.99- \\
4.70 \\
\end{array}$ & $3.14 * *$ & $\begin{array}{l}2.04- \\
4.83 \\
\end{array}$ & $3.56 * *$ & $\begin{array}{l}2.35- \\
5.38 \\
\end{array}$ & $3.42 * *$ & $\begin{array}{l}2.24- \\
5.22 \\
\end{array}$ & $3.36 * *$ & $\begin{array}{l}2.20- \\
5.12 \\
\end{array}$ & $3.25 * *$ & $\begin{array}{l}2.12- \\
4.97 \\
\end{array}$ \\
\hline \multicolumn{2}{|c|}{ Graduate entry } & 1.11 & $\begin{array}{l}0.71- \\
1.76\end{array}$ & $\begin{array}{l}2.04 \\
* *\end{array}$ & $\begin{array}{l}1.37- \\
3.03\end{array}$ & 1.20 & $\begin{array}{l}0.76- \\
1.90\end{array}$ & $2.28 * *$ & $\begin{array}{l}1.53- \\
3.40\end{array}$ & 1.16 & $\begin{array}{l}0.73- \\
1.84\end{array}$ & $2.11 * *$ & $\begin{array}{l}1.41- \\
3.18\end{array}$ \\
\hline \multicolumn{2}{|l|}{ Female } & 1.27 & $\begin{array}{l}0.90- \\
1.80 \\
\end{array}$ & 1.12 & $\begin{array}{l}0.80- \\
1.56 \\
\end{array}$ & 1.29 & $\begin{array}{l}0.91- \\
1.82 \\
\end{array}$ & 1.14 & $\begin{array}{l}0.82- \\
1.58 \\
\end{array}$ & 1.28 & $\begin{array}{l}0.90- \\
1.81\end{array}$ & 1.12 & $\begin{array}{l}0.80- \\
1.56\end{array}$ \\
\hline \multicolumn{2}{|c|}{$\begin{array}{l}\text { International } \\
\text { student status }\end{array}$} & $4.14^{* *}$ & $\begin{array}{l}2.43- \\
7.05\end{array}$ & $7.49^{* *}$ & $\begin{array}{l}4.64- \\
12.1\end{array}$ & $4.20 * *$ & $\begin{array}{l}2.47- \\
7.15\end{array}$ & $7.61^{* *}$ & $\begin{array}{l}4.72- \\
12.3\end{array}$ & $4.14 * *$ & $\begin{array}{l}2.43- \\
7.05\end{array}$ & $7.77^{* *}$ & $\begin{array}{l}4.75- \\
12.4\end{array}$ \\
\hline \multicolumn{2}{|c|}{$\begin{array}{l}\text { Rural return of } \\
\text { service obligation } \\
\text { (BMP or MRBS) }^{b}\end{array}$} & $1.68^{*}$ & $\begin{array}{l}1.13- \\
2.51\end{array}$ & $1.58^{*}$ & $\begin{array}{l}1.06- \\
2.35\end{array}$ & $1.65^{*}$ & $\begin{array}{l}1.11- \\
2.45\end{array}$ & $1.55^{*}$ & $\begin{array}{l}1.04- \\
2.30\end{array}$ & $1.67^{*}$ & $\begin{array}{l}1.12- \\
2.49\end{array}$ & $1.57^{*}$ & $\begin{array}{l}1.05- \\
2.33\end{array}$ \\
\hline \multicolumn{2}{|c|}{$\begin{array}{l}\text { Interest in working } \\
\text { in a rural area }\end{array}$} & 0.98 & $\begin{array}{l}0.57- \\
1.67\end{array}$ & $1.90^{*}$ & $\begin{array}{l}1.16- \\
3.12\end{array}$ & 1.01 & $\begin{array}{l}0.60- \\
1.71\end{array}$ & $2.00 * *$ & $\begin{array}{l}1.22- \\
3.27\end{array}$ & 0.96 & $\begin{array}{l}0.56- \\
1.63\end{array}$ & $1.90^{*}$ & $\begin{array}{l}1.15- \\
3.12\end{array}$ \\
\hline \multicolumn{2}{|c|}{$\begin{array}{l}\text { Interest in } \\
\text { becoming a GP }\end{array}$} & 1.00 & $\begin{array}{l}0.61- \\
1.66\end{array}$ & 0.98 & $\begin{array}{l}0.59- \\
1.61\end{array}$ & 1.00 & $\begin{array}{l}0.60- \\
1.64\end{array}$ & 0.99 & $\begin{array}{l}0.60- \\
1.62\end{array}$ & 0.99 & $\begin{array}{l}0.60- \\
1.63\end{array}$ & 0.98 & $\begin{array}{l}0.59- \\
1.63\end{array}$ \\
\hline \multirow{3}{*}{$\begin{array}{l}\text { PGY } \\
\text { Stage } \\
\text { (ref PGY } \\
1-2 \text { ) }\end{array}$} & PGY 3-4 & 0.80 & $\begin{array}{l}0.52- \\
1.22 \\
\end{array}$ & 0.81 & $\begin{array}{l}0.52- \\
1.24 \\
\end{array}$ & 0.78 & $\begin{array}{l}0.51- \\
1.18 \\
\end{array}$ & 0.80 & $\begin{array}{l}0.52- \\
1.24 \\
\end{array}$ & 0.76 & $\begin{array}{l}0.50- \\
1.16 \\
\end{array}$ & 0.79 & $\begin{array}{l}0.52- \\
1.22 \\
\end{array}$ \\
\hline & PGY 5-6 & $0.35^{* *}$ & $\begin{array}{l}0.20- \\
0.60\end{array}$ & 0.82 & $\begin{array}{l}0.52- \\
1.29\end{array}$ & $0.36^{* *}$ & $\begin{array}{l}0.21- \\
0.61\end{array}$ & 0.84 & $\begin{array}{l}0.54- \\
1.33\end{array}$ & $0.35^{* *}$ & $\begin{array}{l}0.20- \\
0.60\end{array}$ & 0.81 & $\begin{array}{l}0.51- \\
1.28\end{array}$ \\
\hline & PGY 7-9 & $0.56^{*}$ & $\begin{array}{l}0.32- \\
0.96\end{array}$ & 0.58 & $\begin{array}{l}0.33- \\
1.03\end{array}$ & $0.51^{*}$ & $\begin{array}{l}0.29- \\
0.88\end{array}$ & 0.63 & $\begin{array}{l}0.35- \\
1.11\end{array}$ & $0.50^{*}$ & $\begin{array}{l}0.29- \\
0.87\end{array}$ & 0.60 & $\begin{array}{l}0.34- \\
1.08\end{array}$ \\
\hline
\end{tabular}

$* *=\mathrm{P}<0.01 ; *=\mathrm{P}<0.05 ; \mathrm{GP}=$ General Practitioner

This article is protected by copyright. All rights reserved 
a Based on the Modified Monash Model 'large region' is $M M M 2=\geq 50,000$ population and 'smaller region/rural town' is $\mathrm{MMM} 3$ to $7<50,000$ population

${ }^{\mathrm{b}}$ Students on Bonded Medical Places (BMP) or Medical Rural Bonded Scholarships (MRBS) were included as one category as they were equally significant in univariate analysis

${ }^{c}$ Based on questions in the Medical Students Outcomes Database survey, administered at the commencement of the medical course asking students: On completing your basic medical degree, where would you most like to practise medicine?; What area of medicine are you most interested in pursuing?

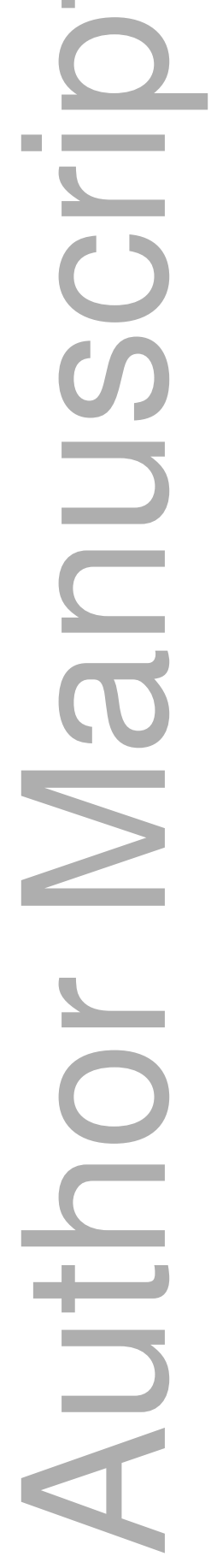


Figure 1: Proportion of students working in rural locations in 2017 by rural-background and duration and setting of rural immersion
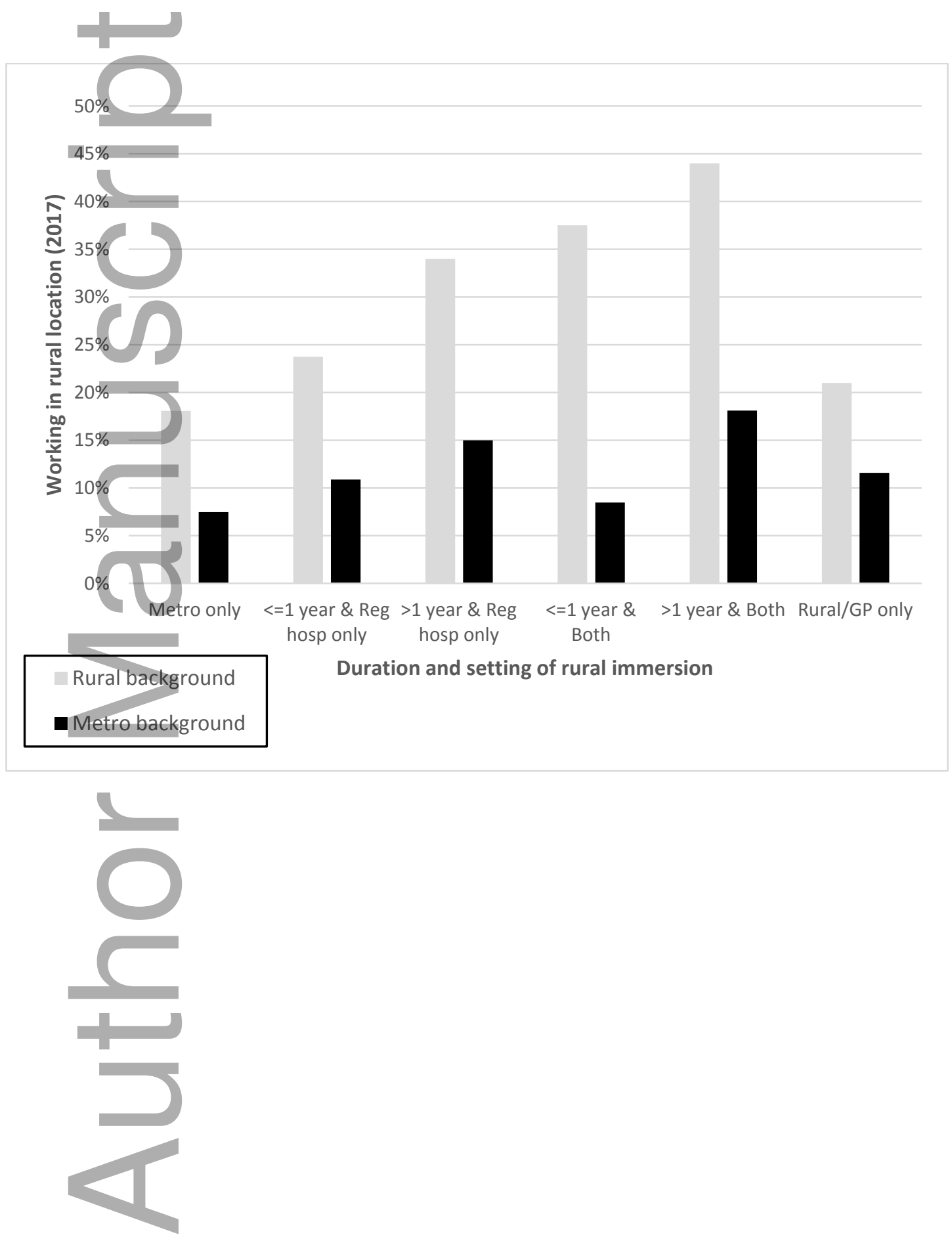

This article is protected by copyright. All rights reserved 


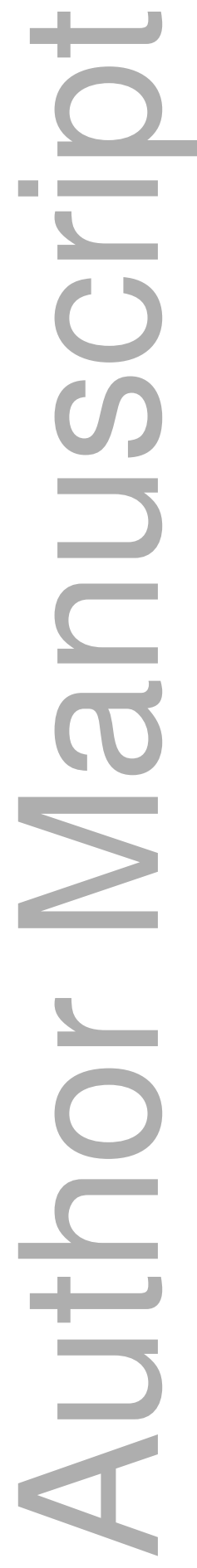

This article is protected by copyright. All rights reserved 


\section{University Library}

\section{- M M N E R VA A gateway to Melbourne's research publications}

Minerva Access is the Institutional Repository of The University of Melbourne

\section{Author/s:}

O'Sullivan, B;McGrail, M;Russell, D;Walker, J;Chambers, H;Major, L;Langham, R

Title:

Duration and setting of rural immersion during the medical degree relates to rural work outcomes

\section{Date:}

2018-08-01

\section{Citation:}

O'Sullivan, B., McGrail, M., Russell, D., Walker, J., Chambers, H., Major, L. \& Langham, R. (2018). Duration and setting of rural immersion during the medical degree relates to rural work outcomes. MEDICAL EDUCATION, 52 (8), pp.803-815. https://doi.org/10.1111/ medu. 13578.

Persistent Link:

http://hdl.handle.net/11343/284160 